\title{
Antibiotic Susceptibility Pattern of Pyogenic Bacterial Isolates in
} Sputum.

\author{
Parveen Anjum ${ }^{1}$, V. Aruna Rajkumari ${ }^{2}$, N. Pavani, Yamini. K, \\ T. Sabarinathan. \\ ${ }^{I}$ Department Of Microbiology, Chalmedaanandrao Institute Of Medical Sciences, Bommakal, Karimnagar \\ 505001, Andhra Pradesh, India. \\ ${ }^{2}$ Department Of Microbiology, Chalmedaanandrao Institute Of Medical Sciences, Bommakal, Karimnagar \\ 505001, Andhra Pradesh, India.
}

\section{Introduction}

Drugs Have Been Used For The Treatment Of Infectious Diseases Since 17th Century, However Chemotherapy As A Science Has Began With Paul Ehrlich In The First Decade Of 20th Century . Paul Ehrlich (1854-1915) Was One Of The Earliest Pioneers In The Field Of Antimicrobial Chemotherapy .1Ehrlich Formulated The Principles Of "Selective Toxicity" ,I.E; Selective Inhibition Of The Growth Of Microorganisms

Without Damage To The Host.2 Resistance Has Been Documented Not Only Against Antibiotics Of Natural And Semi- Synthetic Origin , But Also Against Purely Synthetic Compounds (Flouroquinolone) Or Those Which Do Not Even Enter The Cells (Vancomycin) .3 However, The Euphoria Over The Potential Conquest Of Infectious Diseases Was Short-Lived .Almost As Soon As Antibacterial Drugs Were Deployed, Bacteria Responded By Manifesting Various Forms Of Resistance.4 Considered As "Wonder Drugs" Antibiotics Are Often Prescribed Inappropriately And Inadequately And Have Thus Became One Of The Highly Abused Agents.5

Moreover, The Emergence Of Multi Drug Resistant Organisms Limits The Choice Of Appropriate Therapy.6 The Present Study Was Therefore Undertaken To Find Out Antibiotic Susceptibility Pattern Of Pyogenic Bacteria From Patients Attending CAIMS Using Standard Methods Presently Available, And To Create Awareness Among The Clinicians Regarding The Prevalence Of Antimicrobial Resistance In Pyogenic Bacteria, To Guide The Clinicians To Use Appropriate Antibiotics To Treat Such Bacterial Infections And To Take Appropriate Infection Control Measures So As To Prevent The Further Antibiotic Resistance In Pyogenic Bacteria In CAIMS.

\section{Material \& Methods}

The Present Study Was Carried Out In The Department Of Microbiology , CAIMS , Karimnagar From May 2010 - April 2011 . The Patients Of CAIMS ,Karimnagar Formed The Subject Of The Study. A Total Of 100 Sputum Samples Negative For Acid Fast Bacilli From Patients Having Respiratory Infection Attending CAIMS General Hospital Between May 2010 - April-2011 (12 Months) Were Included In This Study . Pathogenic Organisms Were Isolated And Identified By Conventional Techniques And Tested For Antibiotic Sensitivity.

Antimicrobial Susceptibility Testing Was Done By Kirby Bauer Disc Diffusion Method. Zone Size Measured And Interpreted According To CLSI Standards. ${ }^{7}$ Drug Resistant Strains In Primary Screening Was Further Processed For Detection Of Methicillin Resistance Staphylococcus Aureus (MRSA), Extended Spectrum Beta Lactamases (ESBL) In Gram Negative Bacterial Isolates And Metallo Beta Lactamases (MBL) In Pseudomonas Aeruginosa.

Detection Of MRSA Was Done By Oxacillin Disc (1 $\mu \mathrm{g})$ On The Bacterial Lawn Culture Of S Aureus. After Overnight Incubation, The Zone Of Inhibition Was Measured. An Inhibition Zone Diameter Less Than Or Equal To $10 \mathrm{~mm}$ Indicates MRSA. ${ }^{8}$ ESBL Producers Detected By Combination Disk Method Using Ceftazidime $(30 \mu \mathrm{g})$ And Ceftazidime + Clavulunic Acid $(20 \mu \mathrm{g}+10 \mu \mathrm{g})$ Were Placed At The Distance Of $20 \mathrm{~mm}$ From Center To Center. Plates Were Incubated At $37^{\circ} \mathrm{C}$ Overnight. A > 5mm Increase In Zone Diameter For The Antimicrobial Tested In Combination With Clavulanic Acid Versus Its Zone When Tested Alone Confirmed ESBL Production. ${ }^{9}$ Imipenem Resistant Pseudomonas Aeruginosa Isolates Were Further Screened For MBL Production .Imipenem-Ethylene Diamine Tetra Acetic Acid (EDTA) Double Disc Synergy Test:Test Organisms Were Inoculated On The Plates With Muller Hinton Agar .An Imipenem (10 Microgram) Disc Was Placed $20 \mathrm{~mm}$ Centre To Centre From Blank Disc Containing 10 Microl Of 0.5M EDTA (750 Microgram). Enhancement Of The Zone Of Inhibition In The Area Between Imipenem And The EDTA Discs In Comparison With The Zone Of Inhibition On The Far Side Of The Drug Was Interpreted As Positive. ${ }^{10}$ 


\section{Results}

A Total Of 100 Specimens Were Processed, Out Of Which 37 Were Culture Positives . Out Of Which , Gram Negative Isolates Were Predominant (81\%)

Followed By Gram Positive (18.9\%). We Examined The Antimicrobial Susceptibility Pattern And Simultaneously Screened Them For ESBL And Metallo B-Lactamase Production. The Most Common Organism Isolated Was Klebsiellapneumoniae (45.94\%) , Followed By Pseudomonas Aeruginosa (29.72\%) , Staphylococcus Aureus (13.51\%), CONS (5.4\%), Escherichia Coli (5.4\%) .(Table.1).

\begin{tabular}{|l|l|l|l|}
\hline SL.NO & ORGANISMSISOLATED & NUMBER & $\%$ \\
\hline 1. & Klebsiellapneumoniae & 17 & $45.94 \%$ \\
\hline 2. & Pseudomonas Aeruginosa & 11 & $29.72 \%$ \\
\hline 3. & Staphylococcus Aureus & 05 & $13.51 \%$ \\
\hline 4. & CONS & 02 & $5.4 \%$ \\
\hline 5. & Escherichia Coli & 02 & $5.4 \%$ \\
\hline & TOTAL & 37 & \\
\hline
\end{tabular}

Table 1 :Organisms Isolated In Sputumculture.

The Predominant Organism In This Study, Klebsiellapneumoniae Was Sensitive To Amikacin (94.1\%) ,Gentamycin And Piperacillin / Tazobactam (88.23\%), Followed By Ofloxacin (82.35\%) And Ciprofloxacin $(70.5 \%)$.

It Showed Resistance To Ampicillin ,Cefipime (88.23\%), Cotrimoxazole And Cefotaxime (82.35\%) And Amoxiclav (64.7\%).

The Second Predominant Isolate Was Pseudomonas Aeruginosa Which Showed Sensitivity To Amikacin (90.9) ,Carbenicillin , Piperacillin / Tazobactam , Ofloxacin(72.7\%), And Gentamycin (63.6\%).

It Was Resistant To Ampicillin ,Cefipime And Cefotaxime (81.8\%). The Susceptibility Pattern Shown By Gram Negative Isolates Is Listed In Table.2

TABLE 2: ANTIBIOTIC SUSCEPTIBILITY PATTERN OF GRAM NEGATIVE ISOLATES.

\begin{tabular}{|c|c|l|c|c|c|c|}
\hline \multirow{2}{*}{} & \multicolumn{2}{|c|}{ Number Of Sensitive Organisms } & \multicolumn{2}{l|}{ Number Of Resistant Organisms } \\
\cline { 2 - 7 } Antibiotics & Kleb & Pseudo & E.Coli & Kleb & Pseudo & E.Coli \\
& $(17)$ & $(11)$ & $(2)$ & $(17)$ & $(11)$ & $(2)$ \\
\hline Ampicillin & $02(11.77)$ & $02(18.18)$ & 00 & $15(88.23)$ & $09(81.81)$ & $02(100)$ \\
\hline Amikacin & $16(94.1)$ & $10(90.9)$ & $02(100)$ & $01(5.8)$ & $01(9.1)$ & 00 \\
\hline Amoxiclav & $06(35.3)$ & $06(54.54)$ & $01(50)$ & $11(64.7)$ & $05(45.45)$ & $01(50)$ \\
\hline Gentamycin & $15(88.23)$ & $07(63.6)$ & $02(100)$ & $02(11.77)$ & $04(36.3)$ & 00 \\
\hline Ciprofloxacin & $12(70.58)$ & $06(54.54)$ & $01(50)$ & $05(29.42)$ & $05(45.45)$ & $01(50)$ \\
\hline Ofloxacin & $14(82.35)$ & $08(72.72)$ & $02(100)$ & $03(17.65)$ & $03(27.28)$ & 00 \\
\hline Cotrimoxazole & $03(17.65)$ & - & 00 & $14(82.35)$ & - & $02(100)$ \\
\hline Cefipime & $02(11.77)$ & $02(18.18)$ & 00 & $15(88.23)$ & $09(81.81)$ & $02(100)$ \\
\hline Cefotaxime & $03(17.65)$ & $02(18.18)$ & 00 & $14(82.35)$ & $09(81.81)$ & $02(100)$ \\
\hline Imipenem & $11(64.7)$ & $06(54.54)$ & $02(100)$ & $06(35.3)$ & $05(45.45)$ & 00 \\
\hline $\begin{array}{c}\text { Piperacillin/ } \\
\text { Tazobactam }\end{array}$ & $15(88.23)$ & $08(72.72)$ & $02(100)$ & $02(11.77)$ & $03(27.28)$ & 00 \\
\hline Carbenicillin & - & $08(72.72)$ & -- & - & $03(27.28)$ & - \\
\hline & - & & & - & & \\
\hline
\end{tabular}


Antibiotic Susceptibility Pattern of Pyogenic Bacterial Isolates in Sputum.

Gram Positive Organisms Were Sensitive To Ofloxacin ,Piperacillin/Tazobactam , Imipenem (100\%) Followed By Ciprofloxacin ,Vancomycin (80\%), Amikacin, Gentamycin And Linezolid (60\%). They Were Resistant To Erythromycin (100), Cefotaxime And Cotrimoxazole (80\%) . (Table-3)

TABLE 3:DRUGSUCEPTIBILITY OFGRAM POSITIVE COCCI.

\begin{tabular}{|c|c|c|c|c|}
\hline \multirow{2}{*}{ Antibiotics } & \multicolumn{2}{|c|}{$\begin{array}{ll}\text { Number } & \text { Of } \\
\text { Organisms }(\%) & \text { Sensitive }\end{array}$} & \multicolumn{2}{|c|}{$\begin{array}{ll}\text { Number } & \text { Of } \\
\text { Organisms }(\%) & \text { Resistant }\end{array}$} \\
\hline & $\begin{array}{rll}\mathbf{S} & \cdot & \text { Aureus } \\
(05) & & \end{array}$ & CONS (02) & S.Aureus & CONS \\
\hline Amikacin & $3(60)$ & $2(100)$ & $2(40)$ & 0 \\
\hline Gentamycin & $3(60)$ & $1(50)$ & $2(40)$ & $1(50)$ \\
\hline Ciprofloxacin & $4(80)$ & $1(50)$ & $1(20)$ & $1(50)$ \\
\hline Ofloxacin & $5(100)$ & $2(100)$ & 0 & 0 \\
\hline Cotrimoxazole & $1(20)$ & 0 & $4(80)$ & $2(100)$ \\
\hline Erythromycin & 0 & 0 & $5(100)$ & $2(100)$ \\
\hline Linezolid & $3(60)$ & $1(50)$ & $2(40)$ & $1(50)$ \\
\hline Imipenem & $5(100)$ & $2(100)$ & 0 & 0 \\
\hline Vancomycin & $4(80)$ & $1(50)$ & $1(20)$ & $1(50)$ \\
\hline Cefotaxime & $1(20)$ & 0 & $4(80)$ & $2(100)$ \\
\hline Cefoxitin & $2(40)$ & $2(100)$ & $3(60)$ & 0 \\
\hline $\begin{array}{l}\text { Piperacillin } \\
\text { /Tazobactam }\end{array}$ & $5(100)$ & $2(100)$ & 0 & 0 \\
\hline
\end{tabular}

Out Of 5 Isolates Of Staphylococcus Aureus 3 Were Methicillin Resistant .(FIGURE-1)

Figure-1:INCIDENCE OFMRSA

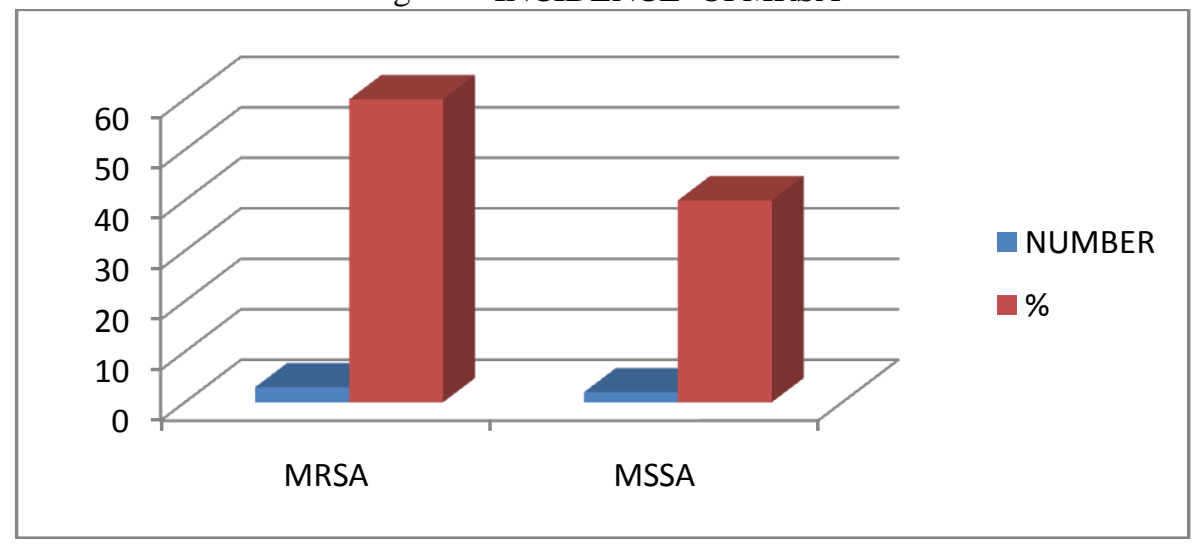

Out Of 17 Isolates Of Klebsiellapneumoniae11, 07 Isolates Of Pseudomonas Aeruginosa Out Of 11 And 1 Isolate Of Escherichia Coli Among 2 Isolates Were ESBL Producers.(Table-4). 
Antibiotic Susceptibility Pattern of Pyogenic Bacterial Isolates in Sputum.

TABLE 4:INCIDENCEOFESBL PRODUCERS.

\begin{tabular}{|c|c|c|}
\hline ORGANISM & ESBL PRODUCER & NON-ESBL PRODUCER \\
\hline $\begin{array}{c}\text { Klebsiella } \\
\text { Pneumoniae } \\
(17)\end{array}$ & 11 & 6 \\
\hline $\begin{array}{l}\text { Psuedomonasaer } \\
\text { uginosa (11) }\end{array}$ & 07 & 04 \\
\hline $\begin{array}{c}\text { Escherichia } \\
\text { Coli(2) }\end{array}$ & 01 & 01 \\
\hline
\end{tabular}

In This Study (27.2\%) Of Pseudomonas Aeruginosa Produced Metallobetalactamase.(FIGURE-2).

FIGURE-2:INCIDENCE OFMETALLO Blactamase IN PSEUDOMONAS AERUGINOSA.

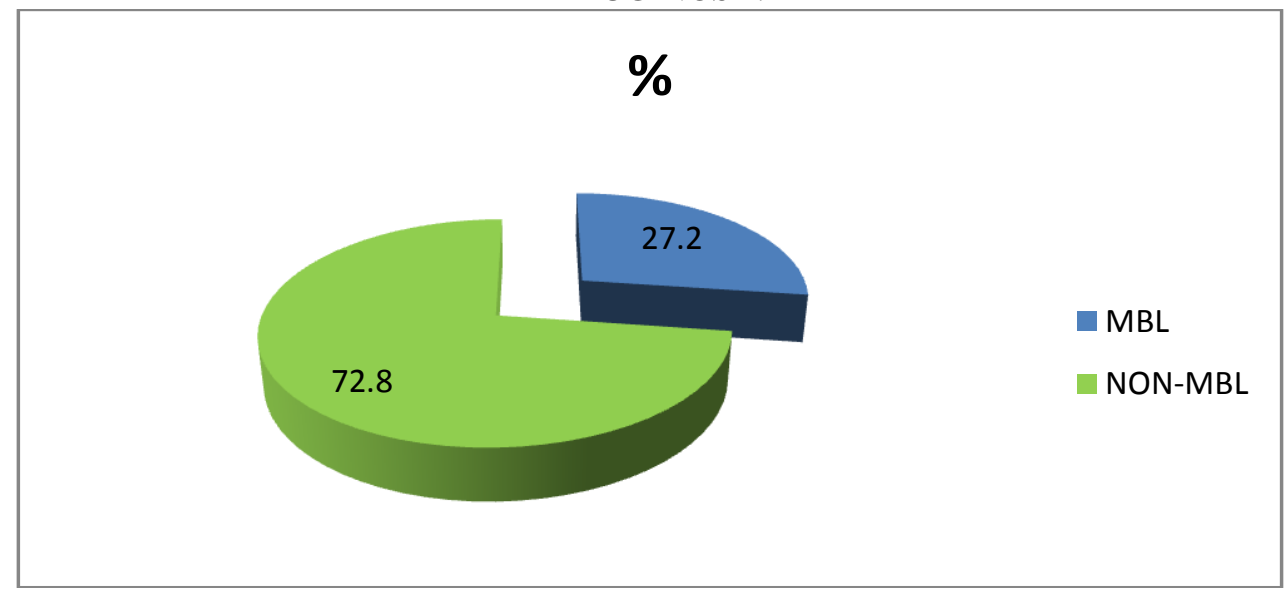

\section{Discussion}

This Study Represented An Attempt To Determine Trends In Antimicrobial Susceptibility Patterns Of The Pyogenic Bacteria Involved In Respiratory Tract Infections.

In Our Study Out Of 100 Samples $37 \%$ Were Culture Positives, Which Is In Accordance With The Previous Studies ${ }^{11}$.Among Them Gram Negative Bacilli Accounted For $30(81 \%)$ Of Positive Samples . The Most Common Gram Negative Bacilli Was Klebsiellapneumoniae (45.9\%) Followed By Escherichia Coli (5.4\%), Pseudomonas Aeruginosa Accounted For 29.7\% . Gram Positive Cocciwas Isolated In 7 (18.9\%) Cases Out Of Which 5 (13.5\%) Were Staphylococcus Aureus And 2 (5.4\%) Were CONS Which Are Similar To The Previous Studies. ${ }^{12,13}$

The Sensitivity Pattern Shown By Klebsiellapneumoniae And Escherichia Coli In Our Study, It Was Sensitive To Aminoglycosides (Ak), Quinolones (Of) And Piperacillin/Tazobactam . It Showed Resistance To Ampicillin ,Cefipime And Cotrimoxazole.

Pseudomonas Aeruginosa Was Sensitive To Amikacin ,Piperacillin/Tazobactam , Carbenicillin And Was Resistant To Ampicillin ,Cefipime And Cefotaxime Which Was Similar To Other Studies. ${ }^{14}$

Staphylococcus Aureus And CONS Were Sensitive To Aminoglycosides ,Quinolones ,Vancomycin, Piperacillin/Tazobactam , Imipenem And Was Resistant To Erythromycin ,Cefotaxime And Cotrimoxazole. ${ }^{15,16}$

The Alarming Finding In The Present Study Was The Resistance In Gram Negative Bacilli To $3^{\text {rd }}$ Generation Cephalosporins Ranging From 55\% To 67\%. This Type Of Resistance Was A Marker For The Presence Of ESBL.

ESBL Production In The Present Study Was (66.6\%). Klebsiellapneumoniae Were The Largest ESBL Producers (36.6\%) Followed By Pseudomonas Aeruginosa (23.3\%). Escherichia Coli Accounted For 3\% Of ESBL Producers.

Carbapenems Are Often Used As Last Resort For Treating Infections Due To Multi Drug

Resistant Gram Negative Bacteria, Because They Are Stable Even In Response To Extended Spectrum B-Lactamases . In Recent Years, There Has Been An Increase In Prevalence Of Carbapenem Resistance Which Is Acquired Metallo B Lactamases Which Is Seen Mainly In Pseudomonas Aeruginosa ${ }^{17,18}$. In Our Study, Out Of 11 Isolates Of Pseudomonas Aeruginosa , 27.2\%(3) Were Found To Be Metallo B Lactam Producers . 


\section{Conclusion}

Present Study Showed The Increasing Trend Of Drug Resistance Among Pyogenic Bacteria Causing Respiratory Infections . It Highlights About Extended Spectrum B - Lactamases (ESBL) Type Of Resistance And Also A Novel Type Of Resistance Mechanism Due To Production Of Metallo B Lactamases . Considered As "Wonder Drugs" Antibiotics Are Often Prescribed Inappropriately And Inadequately And Have Thus Became One Of The Highly Abused Agents. ${ }^{19}$ Moreover, The Emergence Of Multi Drug Resistant Organisms Limits The Choice Of Appropriate Therapy.

Present Situation Needs An Active Interaction Between A Clinician And A Clinical Microbiologist To Minimize The Spread Of Multi Drug Resistant Strains In The Hospitals And To Ensure Authentic Treatment To The Patients.

\section{References}

[1]. Geo F .Brooks, Karen C Carroll, Janet S Butel, Stephen A Morse, Timothy A. Meitzner . Textbook Of Medical Microbiology, 25 Thedn, P.339.

[2]. Ananthnarayan R. Paniker C. K. J. Textbook Of Microbiology. 8th Edition Orient Longman 2009.P.5.

[3]. Connie R.Mahon, Donald C. Lehman , George Manuselis . Textbook Of Diagnostic Microbiology , 3rd Edition. Saunders 2007 ; 450 .

[4]. Braunwald ,Fauci, Kasper, Hauser, Longo, Jameson, Harrison's Principles Of Internal Medicine , $15 n$th Edn , P. 871.

[5]. Fred C. Tenover ., Mechanism Of Antimicrobial Resistance In Bacteria . American J Med , 2006, 119, S3 -S10.

[6]. V Lakshmi ., Need For National/Regional Guidelines And Policies In India To Combat Antibiotic Resistance . 2008 , 26(2) : 105-7.

[7]. National Committee For Clinical Laboratory Standards (NCCLS). Performance Standards For Antimocrobial Susceptibility Testing; Twenty- First Informational Supplement; January 2011, Vol.31 No.1, M100 - S21.

[8]. J. G. Collee, R. S. Miles, B. Watt. Tests For Identification Of Bacteria. In J.Geradaldcollee, Andrew G.Fraser, Barrie P.Marmion, Anthony Simmons, Mackie \& Mccartney Practical Medical Microbiology, $14^{\text {th }}$ Edition. Churchill Livingstone, $2006 ; 135$ - 144.

[9]. Amita Jain, Indranil Roy, Mahendra K. Gupta, Mala Kumar And S. K.Agarwal.Prevalence Of Extended-Spectrum B-Lactamase Producing Gram Negative Bacteria In Septicemia Neonates In A Tertiary Care Hospital. Journal Of Medical Microbiology 2003; 52: $421-425$.

[10]. K Lee, Y S Lim, D Yong, J H Yum, And Y Chong. Evaluation Of Hodge Test And The Imipenem-EDTA Double Disc Synergy Test For Differentiating Metallo-Betalactamase Producing Isolates Of Pseudomonas Spp. And Acinetobacter Spp. Journal Of Clinical Microbiology 2003; 41: 4623-4629.

[11]. Aroma Oberoi ,Arunaaggarwal , Bacteriological Profile , Serology And Antibiotic Sensitivity Pattern Of Micro Organisms From Community Acquired Pneumonia. J JK Scivol.8, No.2, Apr-June 2006.

[12]. A .O .Okesola , O.M Ige, Trends In Bacterial Pathogens Of Lower Respiratory Tract Infections . Ind J Allied Sci And Chest Dis ; 2008 , Vol. 50 .

[13]. Chawlak ,Mukhopadhyay C , Bacteriological Profile And Their Antibiogram From Cases Of Acute Exacerbations Of COPD : A Hospital Based Study. J Clindiag Res , 2008 Feb (2) 612 - 616

[14]. Hossamashour ,Amany El-Sharif, Microbial Spectrum And Antibiotic Susceptibility Profile Of Gram Positive Aerobic Bacteria Isolated From Cancer Patients. J Clinonc. 2007.

[15]. K. Rajaduraipandi, K R Mani, Prevalence And Antimicrobial Susceptibility Pattern Of Methicillin Resistant Staphylococcus Aureus : A Multicenter Study. IJMM 2(24) : 34- 38.

[16]. L U Edirisinghe ,Pankajakalukottage, A Retrospective Observational Study On The Sputum Samples Received By The Department Of Microbiology, Teaching Hospital, Karapitiya In The In The Year 2007. Galle Med J ,Vol 14 (1), Sept 2009

[17]. Gibb AP, Tribuddharat C, Moore RA, Louie TJ, Kruliciki W, Livermore DM, Et Al. Nosocomial Outbreak Of CarbapenemResistant Pseudomonas Aeruginosa With A New [Bla.Sub.IMP] Allele; [Bla.Sub.IMP7].Antimicrob Agents Chemother $2002 ; 46: 255-8$.

[18]. Riccio ML, Franceschini N, Boschi L, Caravelli B, Cornaglia G, Fontana R, Et Al. Characterization Of Metallo-[Beta]-Lactamase Determinant Of Acinetobacter Baumannii AC 54/97 Reveals The Existence Of [Bla.Sub.IMP] Allelic Variants Carried By Gene Cassettes Of Different Phylogeny. Antimicrob Agents Chemother 2000; 44 : 1229-35.

[19]. Fred C. Tenover ., Mechanism Of Antimicrobial Resistance In Bacteria . American J Med , 2006 , 119, S3 -S10. 